\title{
IMPLEMENTASI PENDEKATAN SAINTIFIK PADA MATA PELAJARAN IPS KELAS VII DI SMPN SE-KECAMATAN SERIRIT TAHUN AJARAN 2017/2018
}

\author{
Siti Jawanirotul Makmunah ${ }^{1}$, Lulup Endah Tripalupi ${ }^{2}$, lyus Akhmad Haris ${ }^{3}$ \\ Jurusan Pendidikan Ekonomi, Fakultas Ekonomi \\ Universitas Pendidikan Ganesha Singaraja, \\ Indonesia
}

\begin{abstract}
email: rarahaerani19@gmail.com¹, endah.tripalupi@undiksha.ac.id², akhmad.haris@undiksha.ac.id ${ }^{3}$
\end{abstract}

\begin{abstract}
Abstrak
Penelitian ini bertujuan untuk menjelaskan penerapan pendekatan saintifik, hambatan yang dialami serta solusi yang diambil guru untuk peningkatan penerapan pendekatan saintifik pada mata pelajaran IPS kelas VII SMP Negeri di Kecamatan Seririt. Penelitian ini merupakan jenis penelitian deskriptif. Teknik pengumpulan data yang digunakan adalah dokumentasi, wawancara, dan observasi. Data kemudian dianalisis menggunakan teknik analisis model interaktif oleh Milles dan Huberman. Hasil penelitian menunjukkan bahwa penerapan pendekatan saintifik terdiri dari tiga tahap, yaitu perencanaan, pelaksanaan, dan evaluasi. Dalam tahap perencanaan, guru menyiapkan perangkat pembelajaran serta sarana dan prasarana yang diperlukan. Pelaksanaan proses pembelajaran IPS di kelas VII SMP Negeri se-Kecamatan Seririt, guru sudah menggunakan pendekatan saintifik yang terdiri dari 5 langkah yaitu, mengamati, menanya, mengumpulkan informasi/mengeksplor, menalar/mengasosiasi, dan mengomunikasikan. Tahap evaluasi dilakukan dengan penilain tes maupun nontes. Hambatan-hambatan yang dialami oleh guru yaitu tidak terlaksananya karyawisata, pemahaman siswa terhadap materi masih rendah,dan rendahnya kemampuan membaca sebagaian peserta didik. Adapun solusi yang dilakukan guru untuk mengatasi hambatan-hambatan tersebut adalah menggunakan media alternatif, pemberian remidi dan pengayaan, dan memberikan pelatihan membaca.
\end{abstract}

Kata Kunci: Hambatan, Pembelajaran IPS, Pendekatan Sanitifik, solusi.

\section{Abstract}

This study was aimed at explaining the application of scientific approaches, the obstacles and solutions taken by teachers to improve the application of scientific approaches to social studies classes VII of State Junior High Schools in Seririt Subdistrict. This research was a type of descriptive research. Data collection techniques used were documentation, interviews, and observations. The data was then analyzed using interactive model analysis techniques by Milles and Huberman. The results of the study showed that the application of the scientific approach consisted of three stages, namely planning, implementing and evaluating. In the planning stage, the teacher prepared learning tools and the necessary facilities and infrastructure. The process of social studies learning in class VII of State Junior High Schools in Seririt Subdistrict, the teacher had used a scientific approach consisting of 5 steps, namely, observing, asking, gathering information/exploring, reasoning/associating and communicating. The evaluation phase was carried out by written tests or non tests. The obstacles experienced by teachers were the workshop is not implemented, the understanding of students related to the material being taught was still lacking, and the low interest and reading ability of some students. The solution done by the teachers to overcome those barriers were use of alternative media, provisian of remidial and enrichment, and provide of reading training.

Keyword: obstacle, social studies learning, scientific approach, solutions. 


\section{PENDAHULUAN}

Kurikulum 2013 adalah kurikulum yang berbasis kompetensi sekaligus berbasis karakter (competency and caracter basic curriculum), yang dirancang untuk membekali peserta didik dengan berbagai sikap dan kemampuan sesuai dengan tuntutan perkembangan zaman dan teknologi. Kurikulum ini diharapkan mampu memberikan perubahan baru dalam dunia pendidikan dalam mempersiapkan manusia Indonesia agar memiliki kemampuan hidup sebagai pribadi dan warga negara yang memiliki nilai tambah serta nilai jual agar bisa bersaing, bersanding, bahkan bertanding dengan bangsa-bangsa lain dalam percaturan global. Dalam implementasinya, Kurikulum 2013 didasarkan pada pengembangan seluruh potensi peserta didik agar mampu lebih baik dalam melakukan observasi, memiliki keterampilan bertanya, memiliki daya nalar, dan dapat mempresentasikan apa yang diperoleh atau diketahui setelah menerima meteri pembelajaran di sekolah.

Kurikulum 2013 merupakan seperangkat rencana dan peraturan mengenai tujuan, isi, dan bahan pelajaran serta cara yang digunakan sebagai pedoman penyelenggaraan kegiatan pembelajaran untuk mencapai tujuan pendidikan. Kurikulum ini mulai diberlakukan pada tahun ajaran 2013/2014. Kurikulum tersebut muncul sebagai penyempurna dari Kurikulum Tingkat Satuan Pendidikan (KTSP). Hal ini didasarkan karena adanya penyimpangan KTSP dalam tataran implementasi di lapangan. KTSP setelah dievaluasi terlalu menitikberatkan pada aspek kognitif, bersifat kaku dan formal, kurang inovatif dan kurang menarik bagi siswa. Melalui Kurikulum 2013, penyimpanganpenyimpangan tersebut diubah dan diperbaiki sesuai dengan konsep dan tujuan Kurikulum 2013.

Pembelajaran dalam implementasi Kurikulum 2013 adalah pembelajaran yang tidak lagi berpusat pada guru melainkan lebih berpusat pada aktivitas siswa dan lebih bersifat interaktif. Menurut Kemendikbud (2013) proses pembelajaran yang diterapkan dalam Kurikulum 2013 membina beberapa keterampilan, yaitu keterampilan berpikir, keterampilan akademik, keterampilan penelitian, dan keterampilan sosial.

Kurikulum 2013 dalam pelaksanaannya menggunakan pendekatan yang berbeda dengan kurikulum sebelumnya. Kurikulum 2013 menggunakan pendekatan saintifik (scientific approach) karena pendekatan ini dinilai sesuai untuk pengembangan sikap, pengetahuan, dan keterampilan peserta didik. Pendekatan saintifik dimaksudkan untuk memberikan pemahaman kepada peserta didik dalam mengenal dan memahami berbagai materi dengan menggunakan pendekatan ilmiah, bahwa informasi dapat diperoleh dimana saja, kapan saja, dan tidak tergantung pada informasi searah dari guru. Sejalan dengan pendapat tersebut, Hosnan (2014) berpendapat bahwa pendekatan saintifik adalah pembelajaran yang dapat membuat siswa menjadi aktif, kreatif, dan inovatif dalam mengkonstruk konsep, hukum atau prinsip ketika pembelajaran berlangsung. Selain itu, pembelajaran dengan menggunakan pendekatan saintifik pembelajaran menjadi lebih aktif, pembelajaran berpusat pada siswa, serta guru tidak berperan aktif dalam pembelajaran. Adapun hasil belajar yang diharapkan yaitu mampu melahirkan peserta didik yang produktif, kreatif, inovatif, afektif melalui ranah sikap (attitude), keterampilan (skill), dan pengetahuan (knowledge) yang terintegrasi.

IImu sosial adalah ilmu yang mempelajari perilaku dan aktivitas sosial dalam kehidupan bersama. Sedangkan, Kemendikbud (2013) mengartikan IPS sebagai mata pelajaran yang mengkaji tentang isu-isu sosial yang dengan unsur kajiannya dalam konteks peristiwa, fakta, konsep, dan generalisasi. Mata Pelajaran IPS dalam Kurikulum 2013 tercantum pada struktur Kurikulum 2013 untuk SD/MI dan SMP/Mts.

IPS sebagai pendidikan berorientasi aplikatif, pengembangan kemampuan berpikir, kemampuan belajar, rasa ingin tahu dan pengembangan sikap peduli dan tanggung jawab terhadap lingkungan sosial. Tujuan utama IPS adalah untuk membina para peserta didik menjadi warga negara yang mampu mengambil 
keputusan secara demokrastis dan rasional yang dapat diterima oleh semua golongan yang ada di masyarakat. Selain itu, IPS juga menekankan pada pengetahuan tentang bangsanya, sikap kebangsaan, patriotisme, serta aktivitas masyarakat di bidang ekonomi dalam ruang atau space dalam NKRI.

IPS merupakan salah satu mata pelajaran yang sengaja dirancang dan dilaksanakan untuk mengembangkan karakteristik warga negara Indonesia yang baik khususnya dalam cara berfikir, bersikap dan berperilaku sosial dalam hidup bermasyarakat. Hal ini menunjukkan bahwa IPS bertujuan meningkatkan dan menumbuhkan pengetahuan, kesadaran dan sikap sebagai warga negara yang bertanggung jawab, menuntut pengelolaan pembelajaran secara dinamis dengan mendekatkan siswa kepada realitas objektif kehidupannya, maka dalam pembelajaran IPS, guru perlu melatih keterampilan sosial untuk mengembangkan kecerdasan sosial anak.

Pada jenjang SMP/MTs, mata pelajaran IPS memuat materi Geografi, Sejarah, Sosiologi, dan Ekonomi. Dalam pelaksanaan Kurikulum 2013, pada jenjang Sekolah Menengah Pertama (SMP) mata pelajaran IPS dikembangkan menjadi social integrative studies (IPS terpadu) bukan lagi disiplin ilmu. Pengertian terpadu bukan berarti tidak ada sub mata pelajaran seperti sejarah, Geografi, dan Ekonomi, namun program pembelajarannya harus disusun dari bebagai cabang ilmu dalam rumpun sosial dengan memadukan kompetensi dasar yang ada. Ketercapaian tujuan mata pelajaran IPS didukung oleh proses pembelajaran yang dirancang dalam Kurikulum 2013. Pembelajaran IPS menggunakan pendekatan pengembangan materi ajar yang selalu dikaitkan dengan lingkungan masyarakat di satuan pendidikan yang dikenal dengan istilah pendekatan saintifik.

Pendekatan saintifik dalam pembelajaran IPS menuntut guru agar membiasakan siswa agar meneliti dan memahami fenomena-fenomena yang ada di lingkungan sosialnya. Selain itu, pendekatan ini mendorong peserta didik untuk melakukan serangkaian kegiatan eksplorasi secara langsung maupun tidak langsung di masyarakat melalui langkahlangkah ilmiah. Dengan demikian, pembelajaran IPS menjadi lebih menarik bagi siswa.

Adapun prinsip pendekatan saintifik dalam kegiatan pembelajaran yaitu pembelajaran berpusat pada siswa, membentuk student self concept, terhindar dari verbalisme, memberikan kesempatan kepada siswa untuk mengasimilasi dan mengakomodasi konsep, hukum dan prinsip, mendorong terjadinya peningkatan kemampuan berpikir siswa, meningkatkan motivasi belajar siswa dan motivasi mengajar guru, memberikan kesempatan kepada siswa untuk melatih kemampuan dalam komunikasi, dan adanya proses validasi terhadap konsep, hukum, prinsip yang dikonstruksi siswa dalam struktur kognitifnya.

Pada kelas tujuh siswa berada pada tahap transisi dari siswa sekolah dasar menuju sekolah menengah pertama. Sudah barang tentu mereka harus dibimbing untuk melakukan banyak kebiasaan baru seperti melakukan analisis. Siswa dilatih agar terbiasa untuk melakukan analisis dan merasakan melalui pengalaman langsung bagaimana masalah diselesaikan dengan cara IPS. Keterpaduan IPS memang harus dibiasakan sebagai sebuah cara pandang untuk menyelesaikan masalah-masalah sosial kemasyarakatan sejak mereka duduk di SMP. Diharapkan cara pandang IPS dan kemampuan analisis menjadi kompetensi yang sungguh dimiliki siswa dan bersifat fungsional (Putra, 2012).

Dalam pelaksanaannya, pendekatan saintifik memiliki 5 tahap belajar pokok yaitu, mengamati, menanya, mengasosiasikan/mengolah informasi, dan mengomunikasikan (Kemendikbud, 2013). Sedangkan Menurut Hosnan (2014), proses pembelajaran pada Kurikulum 2013 untuk semua jenjang dilaksanakan dengan menggunakan pendekatan saintifik, meliputi: menggali informasi melalui observing/mengamati, quesioning/menanya, eksperimenting/ mencoba, mengolah data atau informasi, menyajikan data atau informasi, dilanjutkan dengan menganalisis, 
associating/menalar,

kemudian

menyimpulkan, dan mencipta, serta membentuk jaringan/networking. Dalam proses pembelajaran dengan pendekatan saintifik terdapat lima langkah belajar pokok, yaitu mengamati, menanya, mengumpulkan informasi/eksperimen, mengasosiasikan/mengolah data, dan mengomunikasikan. Melalui kelima langkah tersebut, diharapkan dapat mendorong dan menginspirasi siswa berpikir secara logis dan kritis, analitis, tepat dalam mengidentifikasi, memahami, memecahkan masalah dan terampil dalam kehidupan sosial, serta mampu mengaplikasikan materi pembelajaran.

Menurut Mc. Collum (dalam Musfiqon \& Nurdyansyah, 2015) ada empat komponen-komponen penting dalam mengajar menggunakan pendekatan saintifik yaitu, menyajikan pembelajaran yang dapat meningkatkan rasa keingintahuan (foster a sense of wonder), meningkatkan keterampilan mengamati (encourage observation), melakukan analisis (push for analysis) dan berkomunikasi (require communication).

Pada Sekolah Menengah Pertama di Kecamatan Seririt, pembelajaran dengan menggunakan pendekatan saintifik mulai diterapkan pada tahun ajaran 2017/2018. Pendekatan saintifik diterapkan untuk semua mata pelajaran pada kelas VII di masing-masing sekolah. Dalam pengimplementasian pendekatan saintifik dalam pembelajaran guru menemui berbagai hambatan kerena pendekatan saintifik masih terasa asing bagi guru. Oleh karena itu, peneliti ingin mengkaji tentang hambatan-hambatan yang dialami guru dalam pengimplementasian pendekatan saintifik pada mata pelajaran IPS serta solusi yang dapat ditempuh untuk menyelesaikan permasalahan tersebut.

Berdasarkan pemaparan diatas, peneliti merancang sebuah penelitian yang berjudul "Implementasi Pendekatan Saintifik pada Mata Pelajaran IPS Kelas VII di SMP Negeri se-Kecamatan Seririt Tahun Ajaran 2017/2018.

\section{METODE PENELITIAN}

Rancangan penelitian yang digunakan dalam penelitian ini adalah deskriptif.
Penelitian deskriptif adalah penelitian yang dilakukan untuk mengetahui nilai variabel mandiri, baik satu variabel atau lebih (independent) tanpa membuat perbandingan (Siregar, 2010). Penelitian ini memberikan gambaran (deskriftif) secara menyeluruh dalam penerapan pendekatan saintifik pada mata pelajaran IPS kelas VII SMP Negeri di Kecamatan Seririt dan hambatan-hambatan yang dialami guru serta solusi yang dilakukan untuk peningkatan penerapan pendekatan saintifik dalam pembelajaran IPS.

Subjek penelitian ini adalah guru IPS kelas VII SMP Negeri se-Kecamatan Seririt yang berjumlah empat orang yaitu satu guru IPS yang mengajar di kelas VII dari masing-masing sekolah. Adapun objek dari penelitian ini adalah implementasi pendekatan saintifik dalam pelaksanaan pembelajaran IPS kelas VII SMP Negeri se-Kecamatan Seririt.

Penelitian ini dilakukan pada awal semester tahun ajaran 2018/2019 yaitu pada bulan September 2018 yang dilakukan di SMP Negeri se-Kecamatan Seririt.

Teknik pengumpulan data pada penelitian ini menggunakan Triangulasi. Triangulasi merupakan pengecekan data menggunakan beragam sumber, teknik dan waktu (Putra: 2011). Teknik yang digunakan beragam, mulai dari teknik dokumentasi, observasi dan wawancara, serta pengumpulan data yang tidak dilakukan dalam satu waktu.

Penelitian ini menggunakan dua jenis data yaitu data primer dan data sekunder. Data primer merupakan data yang diperoleh dari sumber pertama. Data primer berupa data dari hasil wawancara dan hasil observasi penerapan pendekatan saintifik mata pelajaran IPS. Sedangkan data sekunder merupakan data yang diperoleh dari sumber kedua. Data sekunder pada penelitian ini data berupa dokumen-dokumen perangkat pembelajaran.

Penelitian ini menggunakan teknik analisis data model interaktif oleh Milles dan Huberman. Aktivitas dalam analisis data dilakukan secara interaktif dan berlangsung secara terus menerus sampai tuntas sehingga datanya mencapai titik jenuh. Miles dan Huberman 
(dalam Putra) mengemukakan empat langkah untuk menganalisis data kualitatif yaitu: pengumpulan data, reduksi data, penyajian data, dan penarikan kesimpulan.

\section{HASIL DAN PEMBAHASAN}

Implementasi pendekatan saintifik dalam proses pembelajaran meliputi tahap perencanaan, tahap pelaksanaan dan tahap evaluasi. Pada tahap perencanaan guru mempersiapkan segala perangkat pembelajaran serta sarana dan prasarana yang digunakan selama proses pembelajaran. Tahap pelaksanaan meliputi pengimplementasian langkahlangkah pendekatan saintifik pada pelajaran yang telah disusun sebelumnya dalam RPP. Tahap evaluasi dilakukan diakhir pembelajaran untuk mengukur hasil belajar peserta didik terkait materi pembelajaran.

Perencanaan pembelajaran dilakukan untuk menyiapkan segala kebutuhan yang diperlukan dalam pelaksanaan pembelajaran. Perencanaan merupakan langkah awal sebelum memulai kegiatan. Berdasarkan hasil wawancara dan pengamatan, sebelum memulai pembelajaran di dalam kelas, guru menyiapkan berbagai perangkat pembejaran seperti, Rencana Pelaksanaan Pembelajaran (RPP) yang mengacu pada Kurikulum 2013 dengan menggunakan pendekatan saintifik dan silabus. Selain itu, guru juga menyiapkan Program tahunan, Program Semester, Jurnal, daftar kehadiran peserta didik, dan sarana dan prasarana yang diperlukan. Perangkat pembelajaran ini disiapkan agar proses pembelajaran di dalam kelas berjalan dengan efektif.

Kegiatan pelaksanaan pembelajaran dengan pendekatan saintifik meliputi kegiatan pendahuluan, kegiatan inti, dan kegiatan penutup. Pelaksanaan proses pembelajaran merupakan implementasi dari RPP yang telah dibuat sebelumnya.

Berdasarkan hasil pengamatan terhadap guru IPS kelas VII di SMP Negeri se-Kecamatan Seririt dalam melaksanakan kegiatan pendahuluan yaitu, guru menyapa peserta didik dengan mengucapkan salam, melakukan doa bersama, memeriksa kehadiran peserta didik, kedisiplinan serta kerapian peserta didik dan kelas. setelah dirasa siap, guru mengajak peserta didik untuk melakukan sesuatu yang mampu membangkitkan semangat peserta didik. Kegiatan yang dilakukan berupa tepuk PPK (Penguatan Pendidikan Karakter), salam PPK, menyanyikan lagu nasional, hingga menyanyikan mars sekolah. Selanjutnya guru menyampaikan kompetensi pembelajaran, indikator dan tujuan pembelajaran.

Kegiatan pendahuluan bertujuan untuk menciptakan suasana awal pembelajaran yang efektif dan menyenangkan yang menungkinkan siswa dapat mengikuti proses pembelajaran dengan baik. Kegiatan pendahuluan dalam pendekatan saintifik bertujuan untuk memantapkan pemahaman peserta didik terhadap konsep-konsep yang telah dikuasai yang berkaitan dengan materi pelajaran baru yang dipelajari oleh siswa. Dalam kegiatan ini guru harus mengupayakan agar siswa yang mengalami kesalahan konsep, kesalahan tersebut dapat dihilangkan. Pada kegiatan pendahuluan, guru disarankan untuk menunjukkan fenomena atau kejadian yang aneh atau ganjil (discrepant event) yang dapat menggugah timbulnya pertanyaan pada diri siswa (Hosnan, 2014).

Berdasarkan pengamatan peneliti dapat disimpulkan bahwa kegiatan pendahuluan sangat penting dilakukan dalam pembelajaran IPS. Hal ini disebabkan kegiatan pendahuluan dapat mengefektifkan proses pembelajaran. Dalam kegiatan pendahuluan, hal yang dilakukan oleh guru yaitu: menyiapkan peserta didik secara psikis dan fisik, mengajukan pertanyaan tentang materi yang sudah dan akan dipelajari, mengantarkan peserta didik kepada suatu permasalahan atau tugas yang akan dilakukan untuk mempelajari suatu materi, menjelaskan tujuan pembelajaran atau KD yang akan dicapai dan menyampaikan garis besar cakupan materi dan penjelasan tentang kegiatan yang akan dilakukan peserta didik.

Tahap kedua dalam proses
pembelajaran adalah kegiatan inti.
Kegiatan inti merupakan proses


pembelajaran untuk mencapai tujuan, yang dilakukan secara interaktif, inspiratif, menyenangkan, menantang, memotivasi peserta didik secara aktif menjadi pencari informasi, serta memberikan ruang yang cukup bagi prakarsa, kreativitas, dan kemandirian sesuai dengan bakat, minat, dan perkembangan fisik serta psikologis peserta didik (Hosnan, 2014). Kegiatan inti dalam proses pembelajaran dengan pendekatan saintifik yaitu penerapan dari langkah-langkah pendekatan saintifik.

Pendekatan saintifik yaitu pendekatan yang menggunakan langkah-langkah serta kaidah ilmiah dalam proses pembelajaran. Langkah ilmiah yang diterapkan meliputi menemukan masalah, merumuskan masalah, mengajukan hipotesis, mengumpulkan data, menganalisis data, dan menarik kesimpulan. Tahapantahapan yang dilakukan yaitu mengamati (untuk mengidentifikasi atau menemukan masalah), merumuskan masalah, mengajukan atau merumuskan hipotesis, mengumpulkan data dengan berbagai teknik, menganalisis data dan menarik kesimpulan dan mengomunikasikan konsep, hukum, atau prinsip yang telah ditemukan. Hasil pembelajaran yang diharapkan yaitu peserta didik mempunyai kemampuan sikap, pengetahuan, dan keterampilan secara terintegrasi.

Berdasarkan hasil pengamatan, penulis dapatkan bahwa kegiatan inti yang dilakukan dalam penerapan pendekatan saintifik dalam pelajaran IPS kelas VII di SMP Negeri Kecamatan Seririt adalah sebagai berikut.

Kegiatan pertama dalam pembelajaran dengan pendekatan saintifik adalah mengamati/observasi. Metode observasi adalah salah satu strategi pembelajaran yang menggunakan kontekstual dan media asli dalam rangka membelajarkan peserta didik yang mengutamakan kebermaknaan proses pembelajaran.

Dalam kegiatan mengamati, guru membuka secara luas dan bervariasi kesempatan peserta didik untuk melakukan pengamatan melalui kegiatan: melihat, menyimak, mendengar, dan membaca. Kesimpulan penulis terhadap kegiatan mengamati dalam proses pembelajaran sangat bermanfaat bagi peserta didik karena proses mengamati memberi pengalaman langsung bagi peserta didik dan memenuhi rasa ingin tau peserta didik, sehingga pembelajaran memiliki kebermaknaan yang tinggi.

Kegiatan mengamati pada mata pelajaran IPS di SMPN Seririt dimulai dengan mengamati demonstrasi guru terkait materi pelajaran.luas dan bervariasi kesempatan peserta didik untuk melakukan pengamatan melalui kegiatan: melihat, menyimak, mendengar, dan membaca.

Kesimpulan penulis terhadap kegiatan mengamati dalam proses pembelajaran sangat bermanfaat bagi peserta didik karena proses mengamati memberi pengalaman langsung bagi peserta didik dan memenuhi rasa ingin tau peserta didik, sehingga pembelajaran memiliki kebermaknaan yang tinggi.

Langkah kedua pada pendekatan saintifik adalah menanya/quetioning. Kegiatan menanya adalah mengajukan pertanyaan untuk mendapatkan informasi tambahan tentang apa yang diamati (dimulai darp pertanyaan faktual sampai ke pertanyaan yang bersifat hipotik) (Hosnan, 2014).

Dalam proses pembelajaran IPS di kelas VII SMP Negeri Kecamatan Seririt dilakukan dengan melakukan tanya jawab yang dilakukan saat penyampaian materi. Selain itu, kegiatan menanya juga dilakukan antara sesama peserta didik dengan merumuskan pertanyaan bersama kelompoknya dan diajukan ke kelompok lain.

Penulis menyimpulkan bahwa kegiatan menanya telah dilakukan dengan baik oleh guru dari masing-masing sekolah. Kegiatan ini sangat bermanfaat untuk peserta didik dimana untuk membangkitkan rasa ingin tahu, minat, dan perhatian peserta didik tentang suatu tema atau topik pembelajaran.

Kegiatan mengumpulkan informasi merupakan kelanjutan dari kegiatan bertanya. Dalam Permendikbud No. 81 a Tahun 2013, aktivitas mengumpulan informasi dilakukan melalui eksperimen, membaca sumber lain selain buku teks, mengamati objek/kejadian/aktivitas wawancara dengan narasumber, dan sebagainya. Adapun kompetensi yang ingin diharapkan adalah mengembangkan 
sikap teliti, jujur, sopan, menghargai pendapat orang lain, kemampuan berkomunikasi, menerapkan kemampuan mengumpulkan informasi melalui berbagai cara yang dipelajari, mengembangkan kebiasaan belajar dan belajar sepanjang hayat (Hosnan, 2014).

Kegiatan mengumpulkan informasi dalam pembelajaran IPS dengan pendekatan saintifik di SMP Negeri dilakukan oleh peserta didik yaitu mengumpulkan informasi atau berdiskusi dengan anggota kelompok, dan membaca buku paket serta LKS. Kegiatan ini dilakukan untuk menggali dan mengumpulkan informasi dari berbagai sumber dengan berbagai cara. Kegiatan ini diharapkan dapat menumbuhkan sikap kreatif dan inovatif peserta didik. Kegiatan mengumpulkan informasi mampu mengembangkan keterampilan sosial siswa melalui sikap teliti, jujur, saling menghargai pendapat, dan dapat berkomunikasi dengan baik di dalam kelompoknya.

Proses pembelajaran dengan mengeksplorasi membuka kesempatan kepada peserta didik untuk memperoleh pengetahuan lebih luas, lebih banyak membaca, lebih banyak berdiskusi, dan lebih banyak bertanya serta mengumpulkan informasi tidak hanya dari satu sumber.

Kegiatan asosiasi dalam pembelajaran sebagaimana disampaikan dalam Permendikbud Nomor 18 a Tahun 2013, adalah mengolah informasi yang sudah dikumpulkan, baik terbatas dari hasil mengumpulkan informasi/eksperimen maupun dari hasil mengamati dan mengumpulkan informasi. Kegiatan menalar yang dilakukan oleh peserta didik dalam proses pembelajaran IPS di Kecamatan Seririt adalah peserta didik secara berkelompok maupun mandiri mengolah jawaban yang diperoleh dari pengumpulan informasi dan kemudian disimpulkan. Jawaban kemudian ditulis pada kertas atau buku tugas.

Kesimpulan penulis tentang tahapan menalar ini adalah dalam kegiatan ini peserta didik dapat menemukan satu informasi dengan informasi lainnya, menemukan pola dari keterkaitan informasi tersebut. Selain itu, kegaiatan ini mengembangkan sikap jujur, teliti, disiplin, taat aturan, kerja keras, kemampuan menerapkan prosedur dan kemampuan berpikir induktif serta deduktif dalam menyimpulkan.

Langkah terakhir dalam proses pembelajaran dengan pendekatan saintifik yaitu mengomunikasikan. Kegiatan mengomunikasikan dalam pembelajaran IPS kelas VII di SMP Negeri Kecamatan Seririt dilakukan dengan mempresentasikan jawaban dari permasalahan yang diberikan oleh guru. Selain itu, kegiatan yang dilakukan adalah menyampaikan pertanyaan dan jawaban dalam diskusi antar kelompok. Setiap kelompok menyampaikan jawaban maupun pertanyaan yang telah ditulis sebelumnya.

Pada langkah ini, peserta didik diharapkan mampu mengkomunikasikan hasil pekerjaan yang telah disusun secara bersama-sama dan atau secara individu dari hasil kesimpulan yang telah dibuat bersama. Kegiatan ini dapat dilakukan melalui menuliskan atau menceritakan apa yang ditemukan dalam kegiatan mencari informasi, mengasosiasi, dan menemukan pola. Dalam Permendikbud Nomor 18 a Tahun 2013, kegiatan mengomunikasikan adalah penyampaian hasil pengamatan, kesimpulan berdasarkan analisis secara lisan, tertulis, atau media lainnya.

Kegiatan mengomunikasikan bertujuan untuk mengembangkan sikap jujur, teliti, toleransi, kemampuan berpikir sistematis, mengungkapkan pendapat dengan singkat dan jelas, dan dapat mengembangkan kemampuan berbahasa yang baik dan benar.

Kegiatan terakhir dalam proses pembelajaran adalah kegiatan penutup. Kegiatan penutup di SMP Negeri Kecamatan Seririt diisi dengan tanya jawab terkait materi yang dibahas, memberikan kesempatan kepada peserta didik untuk bertanya apabila ada materi yang belum dipahami. Selanjutnya merefleksikan pembelajaran dan menyampaikan rencana untuk pembelajaran berikutnya. Kegiatan ditutup dengan doa dan salam (paramashanti).

Kegiatan penutup diisi dengan kegiatan guru bersama-sama dengan peserta didik 
membuat kesimpulan, merefleksi pembelajaran yang dilaksanakan secara konsisten dan terprogram, memberi umpan balik terhadap proses dan hasil pembelajaran, merencanakan kegiatan tindak lanjut dalam bentuk pembelajaran remidi, program pengayaan, layanan konseling dan atau memberikan tugas, individual maupun kelompok sesusi dengan hasil belajar peserta didik, dan menyampaikan rencana pembelajaran pada pertemuan berikutnya (Hosnan, 2014).

Kegiatan penutup di SMP Negeri Kecamatan Seririt diisi dengan tanya jawab terkait materi yang dibahas, memberikan kesempatan kepada peserta didik untuk bertanya apabila ada materi yang belum dipahami. Selanjutnya merefleksikan pembelajaran dan menyampaikan rencana untuk pembelajaran berikutnya. Kegiatan ditutup dengan doa dan salam (paramashanti).

Dalam kegiatan penutup terdapat dua hal pokok. Pertama, validasi terhadap konsep, hukum atau prinsip yang telah dikonstruk siswa. Kedua, pengayaan materi pelajaran yang dikuasai siswa.

Tahap pembelajaran ketiga adalah tahap evaluasi pembelajaran. Evaluasi pembelajaran dilakukan pada akhir pembelajaran dengan tanya jawab terkait materi yang dibahas sebelumnya. Penilaian hanya untuk ranah kognitif saja sedangkan untuk ranah sikap dan keterampilan, penilaian tidak dapat dilakukan dalam setiap kali proses pembelajaran. Selain di akhir proses pembelajaran, evaluasi juga dilaksanakan pada saat Kompetensi Dasar telah terpenuhi, pada pertengahan semester dan pada akhir semester dengan pemberian Ulangan Harian, Ulangan Tengah Semester, dan Ulangan Akhir Semester. Penialaian dilakukan dengan pemberian test untuk ranah kognitif dan observasi untuk penilaian ranah sikap dan keterampilan.

Menurut hasil observasi di dan analisis dokumentasi, evaluasi SMP Negeri di Kecamatan Seririt dilaksanakan pada akhir proses pembelajaran, evaluasi juga dilaksanakan pada saat Kompetensi Dasar telah terpenuhi, pada pertengahan semester dan pada akhir semester dengan pemberian Ulangan Harian, Ulangan Tengah Semester, dan Ulangan Akhir Semester dengan tes dan nontes.

Hasil penilaian digunakan oleh guru dan sekolah untuk mengetahui kekuatan dan kelemahan peserta didik dalam satu kelas dan sekolah pada mata pelajaran. Hasil penilaian harus mampu mendorong guru untuk mengajar lebih baik, membantu guru menemukan strategi mengajar yang lebih tepat, dan mendorong sekolah agar memberi fasilitas belajar yang lebih baik.

Implementasi pendekatan saintifik pada mata pelajaran IPS tidak terlepas dari hambatan-hambatan. Berdasarkan hasil penelitian bahwa hambatan yang dialami guru IPS dalam mengimplementasikan pendekatan saintifik dalam proses pembelajaran yaitu, pertama, tidak terlaksananya karyawisata. Karya wisata adalah metode penyajian bahan-bahan pelajaran dengan membawa siswa secara langsung pada objek yang dipelajari dan diatasi di luar kelas. Dalam pelaksanaan karya wisata memerlukan persiapan dan perencanaan yang matang. Selain itu, segala fasilitas yang diperlukan siswa selama melakukan karya wisata sudah disediakan oleh sekolah.

Hambatan kedua adalah pemahaman peserta didik terkait materi yang diajarkan masih kurang. Setiap siswa merupakan individual yang unik dan berbeda satu sama lain. Perbedaan itu dengan sendirinya berpengaruh terhadap cara dan hasil belajar siswa. karena hal ini pula, siswa belajar menurut tempo (kecepatannya) sendiri dan untuk setiap kelompok umur terdapat variasi kecepatan belajar yang berbeda. Kesadaran bahwa dirinya berbeda dengan peserta didik lain akan membantu siswa menentukan cara belajar dan sasaran belajar bagi dirinya sendiri dalam mencapai hasil belajar. Proses pembelajaran klasikal perlu memperhatikan perbedaan ini.

Hambatan ketiga adalah rendahnya kemampuan membaca dari sebagian peserta didik. Keterampilan membaca untuk memahami bentuk-bentuk tertulis merupakan hal mendasar dan sangat diperlukan bagi siswa dalam kegiatan belajarnya. Bila siswa tidak mampu memahaminya secara baik, maka materi 
yang disajikan terasa berat dan efek lebih jauh muncul perasaan bosan untuk mempelajari materi pelajaran. Lemahnya tingkat kemampuan siswa membaca berakibat pada hasil belajar yang semakin jauh dari ketuntasan.

Solusi yang dilakukan guru untuk mengatasi hambata-hambatan dalam peningkatan penerapan pendekatan saintifik pada mata pelajaran IPS di masing-masing sekolah adalah sebagai berikut. pertama, menggunakan media alternatif. Media pembelajaran dikelompokkan menjadi berbagai macam bentuk dan jenis. Media sebagai alat bantu pendidikan dibagi menjadi beberapa klasifikasi menurut fungsi, jenis, dan sumber. Sedangkan menurit sumbernya, media dikelompokkan menjadi media yang berada di dalam kelas, di sekolah, di masyarakat, media bebas dan komersial, media dari tubuh/diri sendiri (body message) dan volunteer. Jika media yang ingin digunakan oleh guru tidak memungkinkan, maka bisa diganti dengan media yang lain atau dengan menggunakan ilustrasi/sosiodrama.

Solusi kedua yaitu pemberian remidi dan pengayaan. Pembelajaran remidial merupakan layanan pendidikan yang diberikan kepada peserta didik untuk memperbaiki prestasi belajarnya sehingga mencapai kriteria ketuntasan yang ditetapkan. Dengan diberikannya pembelajaran remidial bagi peserta didik yang belum mencapai tingkat ketuntasan belajar, maka peserta didik ini memerlukan waktu lebih lama daripada mereka yang telah mencapai tingkat penguasaan. Mereka juga perlu menempuh penilaian kembali setelah mendapat program pembelajaran remidial. Adapun bentuk kegiatan remidial yaitu, memberikan tambahan penjelasan dan contoh, menggunakan strategi pembelajaran yang berbeda dengan sebelumnya, mengkaji ulang pelajaran yang lalu, dan menggunakan berbagai jenis media.

Pembelajaran pengayaan merupakan pembelajaran tambahan dengan tujuan untuk memberikan kesempatan pembelajaran baru bagi peserta didik yang memiliki kelebihan sedemikian rupa sehingga mereka dapat mengoptimalkan perkembangan minat, bakat, dan kecakapannya. Pembelajaran pengayaan berupaya mengembangkan keterampilan berpikir, kreativitas, keterampilan memecahkan masalah, eksperimentasi, inovasi, penemuan, keterampilan seni, keterampilan gerak, dan sebagainya. Jenis kegiatan pengayaan berupa kegiatan eksploratori, yang bersifat umum yang dirancang untuk disajikan kepada siswa, keterampilan proses, dan pemecahan masalah.

solusi terakhir yang dilakukan oleh guru adalah adalah Memberikan pelatihan membaca untuk siswa yang belum lancar membaca saat jam istirahat maupun di luar jam sekolah. Proses pendidikan dan pembelajaran memerlukan keterampilan, baik itu intelektual maupun motorik, sehingga menuntut guru untuk menjadi pelatih yang bertugas melatih peserta didik dalam membentuk kompetensi yang diharapkan

\section{SIMPULAN DAN SARAN}

Berdasarkan hasil penelitian dan pembahasan yang telah dipaparkan pada bab sebelumnya, dapat disimpulkan beberapa hal yaitu penerapan pendekatan saintifik pada mata pelajaran pada mata pelajaran IPS di SMPN se-Kecamatan Seririt telah dilaksanakan sesuai dengan langkah-langkah pendekatan saintifik, namun belum terlaksana secara maksimal karena adanya hambatan-hambatan di masing-masing sekolah.

Adapun hambatan-hambatan yang dialami guru dalam penerapan pendekatan saintifik yaitu tidak terlaksananya karyawisata karena terkendala waktu dan biaya, pemahaman siswa terkait materi masih rendah dan rendahnya kemampuan membaca dari sebagian peserta didik

Solusi yang dilakukan guru untuk mengatasi hambatan-hambatan tersebut yaitu, menggunakan media alternatif berupa sosiodarama, gambar, atau penayangan video yang terkait dengan materi pembelajaran, memberikan remidi dan pengayaandan guru memberikan pelatihan membaca untuk siswa yang belum lancar dalam membaca saat jam istirahat maupun di luar jam sekolah. 
Adapun saran yang dapat disampaikan berdasarkan hasil penelitian yang telah dilakukan adalah bagi guru IPS di SMP Negeri se-Kecamatan Seririt, diharapkan agar melakukan koordinasi atau sharing dengan sesama guru IPS melalui kegiatan Musyawarah Guru Mata Pelajaran (MGMP) sehingga mampu mengatasi hambatan yang dialami dalam pengimplementasian pendekatan saintifik dengan baik.

Saran yang kedua adalah guru IPS dalam pembelajaran dengan pendekatan saintifik diharapkan lebih kreatif dan inovatif dalam menggunakan media pembelajaran yang dapat merangsang aktivitas, kreativitas siswa, dan mampu meningkatkan hasil belajar siswa.

Saran terakhir yaitu bagi peserta didik, dengan penerapan pendekatan saintifik dalam proses pembelajaran IPS, peserta didik dapat lebih aktif dan kreatif sehingga hasil belajar IPS juga meningkat.

\section{DAFTAR PUSTAKA}

Dewi, Anastasia Endah Anastika dan Mukminan. 2016. "Implementasi Pendekatan Saintifik dalam Pembelajaran IPS di Middle Grade SD Tumbuh 3 Kota Yogyakarta". Jurnal Prima Edukasia, Volume 4 Nomor 1, Januari 2016, (20 - 31). Dalam http://journal.uny.ac.id/ (diakses 30 Desember 2017)

Ghony, M. Junaidi dan Fauzan Almansyur. 2012. Metodologi Penelitian Kualitatif. Jogjakarta: Ar-ruzz Media

Hamalik, Oemar. 2007. Kurikulum dan Pembelajaran. Bandung: PT. Bumi Aksara

Hosnan, M. 2014. Pendekatan Saintifik dan Konstektual dalam Pembelaharan Abad 21 (Kunci Sukses Implementasi Kurikulum 2013). Bogor: Ghalia Indonesia

Kurniasih, Imas dan Berlin Sani. 2014. Implementasi Kurikulum 2013: Konsep dan Penerapan. Surabaya: Kata Pena

Kemendikbud. 2014. Permendikbud No. 103 tahun 2013 tentang Pedoman Pelaksanaan Pembelajaran. Jakarta: Kemendikbud.

Kementerian Pendidikan dan Kebudayaan. 2013. Kurikulum 2013
Kompetensi Dasar Sekolah Menengah Pertama/ Madrasah Tsanawiyah. Jakarta: Kementerian Pendidikan dan Kebudayaan

Mulyasa. 2010. Implementasi Kurikulum Tingkat Satuan Pendidikan: Kemandirian guru dan Kepala Sekolah. Jakarta: PT Bumi Aksara

Musfiqon dan Nurdyansyah. 2015. Pendekatan Pembelajaran Saintifik. Sidoarjo: Nizamia Learning Center

Peraturan Menteri Pendidikan dan Kebudayaan Republik Indonesia nomor 60 tentang Standar Pendidikan Dasar dan Menengah.

Perwitasari, Anggar Ari. 2016. "Penerapan Pendekatan Saintifik dalam Pembelajaran IPS di SMP Negeri 15 Yogyakarta". Jurnal Pendidikan IPS. Tersedia dalam http://ejournal.student.uny.ac.id. (diakses 30 Desember 2017)

Putra, Nusa. 2011. Penelitian Kualitatif, Proses dan Aplikasi. Jakarta: PT Indeks Permata Puri Media.

Sinambela, Pardomuan. 2013. "Kurikulum 2013 dan Implementasinya dalam Pembelajaran". Jurnal Pendidikan Tersedia dalam http://jurnal.unimed.ac.id (diakses 13 Maret 2018)

Sufairoh. 2016. "Pendekatan Saintifik dan Model Pembelajaran Kurikulum 2013". Jurnal Pendidikan Profesional, 5(3), (halaman116125). Dalam http://www.jurnalpendidikanprofesio nal.com (diakses 19 Maret 2017).

Suharsaputra, Uhar. 2012. Metode Penelitian Kuantitatif, Kualitatif dan Tindakan. Bandung: PT. Refika Aditama.

Supardan, Dadang. 2015. Pengantar IImu Sosial: Sebuah Kajian Pendekatan Struktural. Jakarta: PT Bumi Aksara

Undang-Undang Republik Indonesia Nomor 20 Tahun 2003 Tentang Sistem Pendidikan Nasional. Jakarta: Kementerian Pendidikan dan Kebudayaan

Yamin, Mohammad. 2009. Manajemen Mutu Kurikulum Pendidikan. Yogyakarta: Diva Pers 